\title{
The PfP Consortium “Community of Experts” Approach to International Security Cooperation
}

\author{
Walter L. Christman *
}

\section{Introduction}

The Partnership for Peace (PfP) Consortium of Defense Academies and Security Studies Institutes epitomizes a fundamental truth: "Long-term security and stability requires more than the transformation of our military forces in terms of new hardware. It also requires a mental transformation.” This assessment of the Consortium was provided by NATO Secretary-General Jaap de Hoop Scheffer in his opening speech at its tenth anniversary celebration in Brussels on 18 June 2008, where he issued a call to reflect, take stock of what the Consortium had achieved, and look ahead. ${ }^{1}$ Citing it as a model for the future as NATO enlarges its concept of "Partnership," the SecretaryGeneral situated the Consortium in the context of three phases of the Alliance's own evolution. First was the Cold War, when NATO concentrated on territorial defense and had no formal relations with countries outside the Alliance. The end of the Cold War afforded the opportunity to build an undivided Europe and required an "open community" approach. In this second phase, the Partnership for Peace became NATO's standard "for successful military cooperation between NATO and non-NATO countries, between big and small countries, and between countries with different geographical regions and with different security traditions." De Hoop Scheffer added that, "PfP not only brought them together-it also brought out the best in them."

In support of these goals, the PfP Consortium developed a wide network of institutions and individuals, including both academics and practitioners. The Secretary-General cited its continuing relevance as it had become "the flagship of Defense Institution Building and plays a major role in security sector reform.” The events of 11 September 2001, however, ushered in the third phase of the Alliance's evolution, forcing it to find answers to challenges that are truly global in nature. This phase, Mr. de Hoop Scheffer argues, "may be the most challenging," but optimism was apparent in his Consortium address:

But what about Partnership? Can we move this concept from the second phase of NATO, where it was created, into the third? Can we ensure that PfP retains its tremendous strategic value, even in this age of globalization? The answer is a clear 'yes.' Because, like NATO, PfP has evolved. Its potential has greatly expanded. And, like the Alliance, it has managed to remain both vibrant and relevant.

Dr. Walter L. Christman is a Visiting Fellow of the Center for Technology and National Security Policy at the National Defense University in Washington, D.C.

1 Jaap de Hoop Scheffer, “Secretary-General's Opening Speech” at the PfP Consortium's tenth anniversary conference at NATO Headquarters, Brussels, Belgium, 18 June 2008. (Secretary General's Private Office manuscript.) 
... In line with NATO's more global outlook, the Consortium's curriculum has increasingly stressed topics that are of global concern, such as combating international terrorism. Moreover the Consortium has also championed new, innovative learning methods, and helped to foster a spirit of academic freedom that I consider a very precious asset. Because only if we put competing ideas to the test will we find the right answers to cope with an ever-changing security environment.

Working to strengthen defense education and research through institutional and national cooperation, the PfP Consortium is a model for capacity building anywhere in the world today where there is a need to help ensure democratic control of armed forces. Initiated in Zurich, Switzerland in 1998, and later formally endorsed by NATO heads of state and government in the Washington Summit Communiqué of April 1999, the PfP Consortium has since its inception organized over 2000 participants into multinational working groups and conferences, bringing together civilian and military representatives from more than 350 organizations from all fifty countries constituting the Euro-Atlantic Partnership Council (EAPC) region. The Consortium's journey has been one of almost continual evolution, adapting its organizational forms as the security community that it was established to support steadily matured and developed. While most of its original clientele has graduated from the status of NATO Partner to NATO Member, the PfP Consortium remains a vibrant and viable model in support of defense education reform, with NATO's attention to the concepts of Partnership enlarging to include engagement with other regions of the world. Accordingly, this retrospective essay will explore not only the Consortium's achievements, but will also highlight some of its major design features throughout its history in order to distill a general model of cooperation. As NATO prepares in 2009 to celebrate its sixtieth anniversary, the PfP Consortium is well positioned to support NATO's global outreach.

\section{Genesis of the PfP Consortium}

The Partnership for Peace Consortium of Defense Academies and Security Studies Institutes was originally established in response to the fact that, despite nearly ten years of foreign assistance efforts after the fall of the Berlin Wall in 1989, there had emerged little to no enduring civilian expertise on defense and security matters in the former communist states of Central and Eastern Europe. While many Western institutions, such as the U.S.-German George C. Marshall Center for European Security Studies in Garmisch-Partenkirchen, had trained a substantial number of civilians from former Warsaw Pact nations on issues of defense management in a democracy, no mechanisms had yet emerged to assist nations to train their own civilians. A recurring phenomenon noted among Western defense planners at the time was how frequently individuals in Eastern Europe circulated from political life to national defense ministries and back to civilian life, never to be heard from again. This turnover of the civilian political leadership in Eastern defense establishments was bewildering and disconcerting to Western 
defense planners. $^{2}$

Dr. Rudolf Joo, a former deputy State Secretary of Defense in Hungary in the early 1990s, and then later a faculty member at the Marshall Center, provided some early insights to the problem. He noted in a 1996 article that, after the first five years of "systemic change," the process of "civilianizing" defense ministries had fallen short of the initial hopes of those who sought a more dynamic transformation of defense management. While acknowledging that the reasons varied, and were often specific to each country, a common feature was an unstable domestic political landscape in which the new democracies experienced frequent governmental and personnel changes. For example, between 1990 and 1994, Poland had five ministers of defense, with Hungary, the Czech Republic and Slovakia having an equally high turnover in sub-cabinet appointments. While short-lived governments and frequent personnel switches among politicians and civil servants had negative implications for establishing democratic political control, the larger problem identified by Dr. Joo was the scarcity of civilian experts and the manifold challenges in developing civilian expertise in democratic control of the armed forces:

Because of the previous excessive concern for military secrecy, these issues were simply excluded from public debate. As a consequence, especially at the outset, very few parliamentarians, civil servants, academic researchers, or journalists had any knowledge of these questions. This was true not only for the former opposition-the new parties which, as a general rule, constituted governments after the first free elections: the ex-Communists and their successor parties, with their political allies, have had no specific defense professional competence, or experience of policy-making in a democratic political setting either. ${ }^{3}$

Joo held that within Central Europe the problems were not everywhere the same, thus solutions could not be uniform either. For example, in some countries of the former Warsaw Pact, the civilian population harbored explicit anti-military feelings. In many, the intellectuals who had participated in opposition movements subsequently went into influential government positions, and often held anti-military views. The result was a shaky framework for developing a coherent dialogue within these nations concerning how best to co-develop models of democratic civil-military relations appropriate to each national situation.

Upon examination, it became apparent to strategic planners in the U.S. Defense Department and NATO that aspiring defense and security-sector professionals in the East, unlike their civilian colleagues in the West, were unable to sustain their connec-

2 Christopher Donnelly, "Reform Realities," in Post-Cold War Defense Reform, eds. Istvan Gyarmati and Theodor Winkler (Washington, D.C.: Brassey, 2002), 42.

3 Rudolf Joo, Democratic Control of Armed Forces, Chaillot Paper 23 (Paris: Institute for Security Studies of WEU, February 1996); available at www.iss.europa.eu/uploads/media/ cp023e.pdf. 
tions with each other once outside of government. ${ }^{4}$ Neither were they able to share their talents, abilities, and knowledge with their counterparts in other nations. The initial concept behind the strategic planning of the PfP Consortium, therefore, was to cultivate and sustain civilian competence in defense affairs in the East by developing enduring ties with the defense education and security studies establishments of the West. The PfP Consortium was conceived to enlist Eastern Europeans in the creation of a multinational "community of practice" within the Euro-Atlantic defense community. It would address the post-Cold War needs within the civil societies of both mature and emerging democracies for new intellectual tools in support of democratic control of armed forces.

NATO and U.S. strategic planners thus sought to promote a new defense education system in the East, and sought better connections between Allied and Partner nations in two areas. For the military senior service schools in Eastern Europe, known in the West as National Defense Academies, a mechanism was needed to help shape a shared vision regarding defense and military educational curricula suitable for democratic states. For defense civilians trained outside the military educational system, more intensive linkages between think-tanks and security studies institutes (including civilian universities) could help to cross-fertilize the security sector elements of civil society.

This is easily said, but how is it best achieved? In reviewing ongoing efforts, NATO and U.S. planners concluded that there was much wasteful duplication and overlap that pointed to an urgent need for better coordination of Western assistance efforts. But these strategic planners had only a superficial understanding of the many varieties of Western models upon which to draw, and were neither interested nor qualified to identify which Western model best fit which Eastern need. For ten years after the fall of the Berlin Wall, countless technical visits from NATO countries had been politely received in the capitals of the former Warsaw Pact nations, promoting highly diverse expressions of the role of armed forces in a democracy. Eventually, it became clear that experts from the NATO nations and emerging civilian defense specialists from the former communist Partner nations needed a better mechanism in order to "find each other" and "just sort this stuff out among themselves."

Furthermore, U.S. planners were uncomfortable with the degree to which U.S. expertise in the planning, programming, and budgeting system (PPBS) had been offered as a model for defense management. Differences in scale notwithstanding, U.S. DoD planners were skeptical that the model worked very well even in the United States. Sympathetic to these concerns, Dr. Chris Donnelly, a key advisor to the NATO Secretary-General, suggested that Britain's model of a strong civilian-administrative component in the Ministry of Defense offered an alternative example. Others pointed to France's legal and political experience in the sharing of tasks and authority between

\footnotetext{
The U.S. Joint Staff's key civilian analyst Joshua Spero made this point forcefully in U.S. interagency discussions during the period 1994-96. Having joined the Joint Staff from a civilian academic post at the U.S. National Defense University, Spero had gained particular insight into this problem while doing research on emerging civilian leaders in the defense establishments of Eastern Europe.
} 
the main constitutional actors in security and defense policy. Germany's concept of Innere Führung, with its focus on leadership and civic education in the armed forces, was perhaps the most rigorous model that relied upon the input of civilian educational institutions. Also worthy of mention were the Spanish and Portuguese transitions from military dictatorship to democracy, which offered additional insights to share. While Western models could not simply be copied by the new democracies, owing to unique historical and sociological realities, these experiences might be taken into consideration when developing new civil-military relations in Central and Eastern Europe. ${ }^{5}$ The task at hand was to identify some way to establish a learning environment in which a community of specialists might flourish.

\section{Launching the PfP Consortium: Mobilizing Knowledge Activists in the "Consortium of the Willing"}

The PfP Consortium was initiated with the intention of creating a "community of experts” willing and able to promote more effective defense reform, civil-military cooperation, and military interoperability, with priority given to organizing the civilian element. The Consortium's initial concept paper prepared by the U.S. Office of the Secretary of Defense held that, among its objectives, the single most important principle was the notion that "it will be for the participating countries to fully define and develop both the scope for the Consortium and how it will operate."6 The Consortium was initiated as an international cooperative arrangement "in the spirit of" the Partnership for Peace. While the U.S. and Germany offered to assist in the Consortium's administration, employing the Marshall Center in support of these efforts, Switzerland took the lead role in soliciting international interest and participation, using the Third International Security Forum Conference held in Zurich in October 1998 as a vehicle to mobilize widespread interest. The Swiss greatly aided in the push for NATO-EAPC summit-level endorsement in April 1999. Bulgaria volunteered to host the first major Consortium event following the summit, and facilitated the development of its internal structures.

While a major element of change over the first decade of the Consortium's life has been NATO's adaptation to new security realities and the progressive improvement in its member states' capabilities, the transformational imperatives of non-hierarchical Information Age cooperation have been the key drivers of its own success. Two Swiss theorists provide critical insight about this latter trend. The first, Andreas Wenger, director of the Center for Security Studies of the Swiss Federal Institute of Technology

Joo, Democratic Control of Armed Forces.

6 During the 12 June 1998 Euro-Atlantic Partnership Council (EAPC) Defense Ministerial meeting in Brussels, U.S. Secretary of Defense Richard Cohen formally proposed the creation of a Partnership for Peace Consortium of Defense Academies and Security Studies Institutes. German State Secretary Simon endorsed this proposal and agreed to support it, through the German contribution to the George C. Marshall Center. The group of defense ministers warmly greeted a summary statement provided by the co-sponsors, and with this document serving as an initial charter, the Consortium effort commenced immediately. 
in Zurich and a key observer-participant of the PfP Consortium, has argued that the advent of new information technologies has spread power and authority beyond their traditional owners, the nation-state. As Wenger notes, this diversification of actors due to the rise of the Internet has meant that "speed, capacity, and flexibility in collecting, producing, and disseminating information have increased. As a result of the fragmentation of authority and the altered quality of power, the traditional foundations of security have also been turned upside down.,"7

Another Swiss theorist, Etienne Wenger, who is famous for having coined the phrase "communities of practice," provides the additional observation that a shared community naturally forms around the co-development of a shared body of knowledge, and that people working in large organizations learn the most from working in small groups of like-minded colleagues with whom they share a professional interest and can interact on a regular basis. In the case of the PfP Consortium, this has proven to be true for defense and military professionals from many nations whose common interest was to promote organizational change in institutions that are by nature highly conservative and structured around hierarchical notions of leadership and authority. Small working groups of the kind promoted by the Consortium-groups in which, in Etienne Wenger's terms, "membership is based on participation rather than on official status," and which "are not bound by organizational affiliations"-are able to "span institutional structures and hierarchies," and thus allow participants to gain access to the most versatile and dynamic knowledge resources available. ${ }^{8}$

The Consortium's organizational components, processes, and interactions were expressly designed to create a "community of practice" composed of a loosely organized but robust network of scholars and experts in regional security and defense reform. One aim was to build a cadre of professionals and security specialists in government and the private sector in Partner nations with expertise in a wide variety of defense issues, including defense strategy, parliamentary oversight, public information policies, etc. Another aim was to facilitate greater information-sharing in Partner countries about Euro-Atlantic and European security institutions, particularly in the absence of NATO information offices in most Partner countries. An equally important goal was to provide a forum to assist private foundations, think-tanks, universities, and governmental and non-governmental agencies in offering practical assistance to enhance the quality of defense education in the nations of Central and Eastern Europe.

The challenge for strategic planners in developing the PfP Consortium was to cultivate a "capacity building" process that would help defense educational institutions focus on adaptation and change. Their beliefs about civil-military relations, technologies,

7 Drawn from Dr. Wenger's invitation letter to a 23-25 May 2005 international conference on the information revolution and the changing face of international relations and security in Lucerne, Switzerland. It was jointly hosted by the Center for Security Studies (CSS) at the Swiss Federal Institute for Technology (ETH) Zurich and the Comparative Interdisciplinary Studies Section (CISS) of the International Studies Association (ISA).

8 Etienne Wenger, “Communities of Practice: Learning as a Social System,” Systems Thinker; available at www.co-i-l.com/coil/knowledge-garden/cop/lss.shtml (accessed April 2008). 
the emerging nature of conflict, and the concept of a flexible and adaptive military force suggested the need to facilitate a vision of bottom-up knowledge creation that could emerge from within a community of experts formed in small "working groups" and "study groups." The Consortium's knowledge activists furthered the transfer of knowledge by energizing and connecting efforts throughout the Euro-Atlantic community. All were volunteers, operating largely in their private capacities as technical experts without any real reference to national agendas, the imperatives of the nation-state, or the international system. Their vision was firmly connected to building intellectual capacity and shaping a competent security sector within civil society that emphasized civilian performance as a measure of success. This occurred in three related domains: defense and military education and research; institutional and national cooperation; and contemporary security challenges.

The key to understanding the Consortium model and its potential for future replication is the study/working groups, projects, and boards and their support apparatus. The PfP Consortium supported participants in knowledge creation efforts through three functions: an operations staff headed by an executive director, the development of a journal and related publications, and the administration of a website. During the history of the Consortium, there have been six major and fully robust working groups, eight study groups, four projects, and two boards (in this accounting a couple of study groups have been renamed as working groups, or vice versa). New groups were formed because two or more participants or organizations were interested in working collaboratively on a specific issue, project, or idea. The only rule was that they adhere to the principle that participation be open to representatives of all Euro-Atlantic Partnership Council (EAPC) signatory nations. Each group was semi-autonomous, setting its goals, selecting its chairperson(s), and determining its work and meeting schedules in collaboration with the Consortium's operations staff located at the Marshall Center. The operations staff supported the Consortium on a day-to-day basis by coordinating resources, including identifying potential members and experts, arranging for travel, assisting in finding meeting facilities, and advertising those activities and supporting virtual collaboration through communications technologies such as the Internet.

Study groups focused on intellectual exploration or development of an idea or issue; working groups usually had one or more projects, and were thus focused on the attainment of a definable goal or end state. Projects, in some cases, continued to function for a short time after the working group had completed its developmental work. Boards served to advise the Consortium Steering Committee and Senior Advisory Council on issues that affected the entire Consortium member population. The Steering Committee served as a forum for the working group chairs to discuss ideas and issues that affect the entire Consortium. It helped to ensure widespread distribution of information and coordination of all the Consortium's activities. The Senior Advisory Council, on the other hand, was primarily a donor platform for allocating resources and coordinating inputs at the strategic level.

For the first half of its history, the study/working groups presented their work during the Consortium's annual conferences. Between conferences, the study/working groups met as necessary to achieve the goals and aims that the groups had established; 
between meetings, the individuals in the groups carried out their work via the Internet. Although the Consortium's working group activities were eventually reduced in scope as the process matured from community building to being more project-oriented, the following is a list of the various study/working groups and projects that animated the Consortium during its most robust phase (around 2004). ${ }^{9}$

\section{Working Groups}

- Advanced Distributed Learning (ADL) Working Group

- Curriculum Development Working Group

- Combating Terrorism Working Group

- Military History Working Group

- Security Sector Reform Working Group

- Archives Working Group

\section{Study Groups}

- Crisis Management in Central Asia Study Group

- Crisis Management in South East Europe Study Group

- Crisis Management in the Southern Caucasus Study Group

- European Security (ESDI/CESDP) Study Group

- Future of NATO Study Group

- Study Group on Nonproliferation and Export Controls

- Impact of Information Technology on National Security Study Group

- Economic and Legal Aspects of Security Study Group

Projects

- Information Technology (IT) Project

- Lessons Learned Project

- Modeling and Simulation (M\&S) Project

- Digital Library Project

\section{Boards}

- Publications Board

- Research Board

Defined explicitly, the most valuable work of the PfP Consortium's working groups and other activities consisted of creating a dialogue on multinational security cooperation. The simple existence of these dialogues_-bringing together military staff, educators, and policy makers-is evidence of the emergence of new norms as a dependent

9 As cited on the PfP Consortium website at www.pfpconsortium.org, assessed July 2005. 
variable of structure. These conversations either helped confirm the existence and content of knowledge relevant to defense and security cooperation within the EuroAtlantic region, or aimed to create new knowledge. The most eloquent presentation of the Consortium's contributions came from a Bulgarian officer - Colonel Valery Ratchev, Deputy Commandant of the G.S. Rakovski Defense and Staff College in Sofia, Bulgaria. Based upon his first-hand experiences participating in the Consortium, Col. Ratchev argued that:

Never before has military knowledge and practice been internationalized to the extent that it is today. Removing ideological differences-in particular in the rise of the new common threat perception-is opening a process of a scope and dimension previously unknown to us. None of our countries is able to deal independently with that problem. Internationalizing our efforts in education is not modernism, but is a vital necessity coming from the realities of the time we live in. Mutual opening of the military educational system means commonality of strategic cultures. In this process, everyone can be a beneficial contributor. Here there are not small and big, because there is not a monopoly on the knowledge. The Consortium of Defense Academies and Security Studies Institutes is one of the few brilliant ideas in this aspect. It is worth investing in it. It should be further developed as a model for relationships because it erases unnecessary borders between national and international, between military and civilian, between cultures and policies. ... Everyone who knows the Consortium from the inside knows that one thing is obvious: the people participating in the working groups are closer together in terms of culture, mentality, ambitions, and capacity than the others, and there have been enough significant results that this is the answer to those asking, "What is the Consortium working for?"10

At the same time, the process of managing dialogue was a critical element in the process of knowledge creation, as was ensuring that the dialogue took tangible form. Relevance in the Consortium was largely a function of building a trusting environment without any particular nation attempting to impose its point of view upon all. The PfP Consortium was especially effective in creating such an open and trusting environment, primarily through the early generous support and collaboration of key institutional leaders, such as Dr. Robert Kennedy, Director of the George C. Marshall Center for Security Studies; Ambassador Theodor Winkler, Director of the Geneva Centre for Democratic Control of the Armed Forces; General Raimund Schittenhelm, Commandant, Austrian National Defence Academy; and Mr. John Berry, Dean of the NATO Defense College. During the period 1999-2003, the operations staff of the Consortium, led by Lieutenant Colonel Kirk Murray and Kevin Morgan, coordinated an extraordinary array of meetings and activities for more than twenty groups (many of which were highly active, a couple of which barely existed on paper). They established a formidable array of publications, covering the full range of security studies to serve the military, civilian, and academic needs of the Consortium membership and the international

${ }^{10}$ Colonel Valery Ratchev, Remarks to the Panel on Education and Training, Discussion Topic: "Challenges to Security and Defense Related Education and Training." Cited in the Final Report of the PfP Consortium Sixth Annual Conference, Berlin, 16-17 June 2003. 
community, including the quarterly journal Connections and the occasional series of Athena Papers. ${ }^{11}$

\section{The PfP Consortium in Support of NATO Training Transformation}

When Consortium members had established a trusting atmosphere, possibilities emerged for the generation of new concepts, born of a process of comparing national experiences, organizational differences, and the inherent civil-military dichotomy. By 2003, according to Major-General Federico Yaniz of the NATO Headquarters, International Military Staff, the results were impressive:

In the area of experimentation and training, the Consortium's educational developments lead NATO's transformation efforts. NATO is currently adopting the Consortium's advanced distributed learning systems, in direct cooperation between the NATO staff and the PfP's Advanced Distributed Learning Working Group. This working group is clearly the European focal point of international learning development, not only through its doctrinal expertise, but also through a number of very successful projects including both software and course development. ${ }^{12}$

In turn, these new concepts had to be justified in terms of relevance to the organizational values, strategies, and distinctive experiences of diverse members. The Consortium's Curriculum Development Working Group at its peak had regular participation from more than twenty countries in meetings held two to three times per year. In various groups and subgroups it promoted excellence in curriculum development and course accreditation. It worked on a multilateral basis in support of the development, accreditation, validation, and electronic distribution of curricula in defense management and security policy. It collected existing curricula from member institutions and sought to develop a consensus on curriculum content on cross-functional issues, which was felt to be the most strategic level. It established a database archive on curricula in order to create and sustain a cooperative network in security and defense education. The aim was to grant easy access to existing courses relating to security policy and international relations via an electronic collection of curricula that will provide information on the objects, target groups, outlines, and content of courses. The database had over three hundred individual curricula, collected from more than fifty institutions.

Given that the primary impetus of the PfP Consortium was to promote civilian competence in security affairs and avoid "military hegemony," great emphasis was placed on producing an intellectual consensus. This was best represented by the efforts of the Curriculum Development Working Group to bring together scholars from Allied and Partner nations to produce consensus "reference" curricula on a number of strategic topics relevant to European security cooperation. The basic understanding was that

11 For a complete description of publications and access to their archived issues, see the publications section of the Consortium website at https://consortium.pims.org/publications.

12 Plenary session remarks made during the PfP Consortium's sixth annual conference in Berlin, 15 June 2003; available at https://consortium.pims.org/pfp-consortium-events/6thannual-conference/6th-annual-conference-final-report. 
for a given topic, such as "peace support operations," there exists a bounded body of knowledge that any practitioner should know. Yet individual, institutional, and national positions on this topic vary considerably. The working group sought to produce a general consensus on the main elements of a given topic in sufficient depth and breadth (supported by recommended references and literature) so they might be employed in a wide variety of classroom and other settings in order to promote a more broadly shared understanding of the topic. By the end of 2004, it had produced reference curricula on:

- National Security

- Civil-Military Cooperation

- Peace Support Operations

- International Humanitarian Law

- Security Challenges

- Revolution in Military Affairs

- European Security and Defense Policy and Trans-Atlantic Relations.

Dr. Alexey Victorovich Surin, Dean of the School of Public Administration of Moscow State University and a long-time participant in the PfP Consortium's Curriculum Development Working Group, provided the following evaluation of the relevance of this work: ${ }^{13}$

The PfP Consortium is effective and useful because it helps us with three different tasks. First, it asks experts to explain what they are doing in their own way, in their schools and in their countries. It does this by helping us to combine together our experiences, so that we can see what each holds important and what is held in common. ... Second, it allows for innovative approaches. We can ask what kinds of new approaches have been taken and what are the results. This allows us to observe the experience of others, perhaps enjoying the best and avoiding the worst. Third, we take upon ourselves the role of communicating to others in our countries outside of the Consortium what might be of use. ... The PfP Consortium is a vibrant community of experts, both military and civilian, but the civilians are more likely to shape the process of change. ... Military academies are conservative, and are not likely to transmit these concepts to the broader society.

As time, experience, and trust allowed, some working groups began to create prototypes or special projects to explore the possibility of codifying a "best practice" in terms of a demonstration for wider illustration. For example, the Advanced Distributed Learning (ADL) Working Group, whose topic is more popularly known as "e-learning," played a significant role in coordinating knowledge-creation initiatives. The ADL Working Group developed an open-source Partnership for Peace Learning Management System (PfP-LMS) and a web-based knowledge portal for use by the Consortium, which also became the foundation for NATO's own ADL program. Through its Cooperative Development Teams, the ADL Working Group has supported numerous organizations wishing to convert selected existing courses into web-based interactive

${ }^{13}$ Interview with author in Reichenau, Austria, 13 September 2005. 
courseware for inclusion in the PfP-LMS. In the process, it promotes cooperation with organizations from both Allied and Partner countries and, where possible, with private industry.

The ADL Working Group has been the Consortium's primary engine for shared course development, and considerable emphasis has been placed on capacity building among member organizations to be able to produce online educational content. The ADL Working Group has spawned several prototype initiatives to cross-fertilize one another by communicating more extensively rather than duplicating work. As of 2006, the working group had completed forty-eight ADL courses to support NATO, PfP, and other international organizations. ${ }^{14}$ It had also trained more than a dozen teams from as many nations in the development of ADL course modules. The total usage of online courses developed under the auspices of the PfP Consortium skyrocketed, and resulted by 2007 in over 50,000 online course completions. ${ }^{15}$ It continues to support both classroom activities and PfP exercises, such as the Viking series of exercises hosted by Sweden. PfP-generated ADL courses are, at the time of this writing, also a mandatory part of the curriculum at both the NATO School in Oberammergau, Germany and the NATO Defense College in Rome.

\section{Evaluating the PfP Consortium’s “Community of Experts” Approach}

Evaluating the effectiveness of the Consortium through quantitative measures has been from its inception a problematic issue. The primary benefits of the Consortium, such as trust between nations, are intangible and difficult to quantify. Furthermore, the process of measuring often changes that which is measured, or distorts otherwise good objectives in favor of goals that are of considerably less worth, but are more easily quantifiable. The Consortium's focus on metrics and measurement has at times appeared to be a surrogate arena for disagreement among military and civilian officials about the utility of "conference diplomacy," particularly since the topic under discussion is the participation of civilian academics.

The most difficult challenge the Consortium as a whole has had to confront is to identify and measure its effectiveness and output, when the real issue-questions concerning "whose identity" and "whose effectiveness"-might be more rhetorical weapons than units of measurement. Some senior military officers (both among Allies and Partners) who would have no difficulty recognizing the value of having military officers from different nations engaged in productive dialogue on topics of professional relevance nonetheless disparaged the Consortium's gatherings of civilians to do the same. They tended to overlook the fact that their own professional careers had been groomed and controlled, with programmed rotational assignments and a mandatory progression of formal education, without questioning how civilians might also acquire

14 Courses may be accessed either through the PfP Consortium website or through the Allied Command for Transformation site, at www.act.nato.int/adl.

15 Statistic provided to author by ISN staff managing the PfP Consortium Learning Management System, December 2006. 
sufficient education in the exercise of authority in the control of armed forces in a democratic society. The tensions inherent in mutual obligation within the Consortium have been found at almost every level of analysis: between Allies and Partners, between civilians and military, between scholars and technocrats. Nevertheless, the level of activities carried out in the name of the Consortium suggest that all sides valued the effort to move toward a shared body of knowledge, the value of which is found only in community, which ascribes its worth.

After a robust period of community development from 1998-2004, the Consortium made a turn toward greater accountability for products and output that could be measured as deliverables in support of donor objectives. This was partly due to the fact that the original security community that the Consortium was established to serve had largely matured, particularly as a result of NATO's Prague Summit in 2002, by which time ten Partner nations had achieved NATO membership or an invitation to join the Alliance. At the Istanbul Summit in 2004, focus shifted to give greater attention to the Partner nations in the Caucasus and Central Asia. Accordingly, there was less demand for large numbers of working groups to support major community-wide conferences, and greater need for focused and targeted programs of assistance.

The Consortium's transformation toward the project-oriented approach was guided by two successive executive directors, Bruce McLane and Henri Bigo, and the Consortium found new purpose in responding to the Education and Training for Defense Reform Initiative (EfR) in support of the Istanbul Summit's Partnership Action Plan for Defense Institution Building (PAP-DIB). The EfR commenced in 2006 and enabled the PAP-DIB to become more operationally focused. In support of these goals, it conducted in-depth peer reviews of Partner nations' defense colleges to help raise standards of professional military education, conducted educator workshops to share innovative teaching methods, and developed a reference curriculum converting the Summitapproved PAB-DIB goals into academic courses. A regionally-oriented curriculum for the Greater Black Sea area was explored to promote a shared security vision for the region, seeking to harmonize views of common security challenges.

The Consortium, therefore, has undergone the full spectrum of development. The early stages were simply to explore its potential, allowing people in similar situations to begin meeting without the benefit of shared practice and discover commonalities. Over time, the members began to recognize the potential offered by the Consortium's model, and started exploring methods of connectedness, defining joint enterprises, and negotiating roles within the community. Many individuals—such as Colonel Valery Ratchev in Bulgaria, who later became Bulgaria's Ambassador to Iraq, and Dr. Surin in Russia, who fostered a wider acceptance of curriculum reform-found their voice and moved from the periphery to the center of the "community of experts," thus making the Consortium one of the only entities that offered to help aspiring defense and security sector professionals in the East to sustain their connections with each other once outside of government. For over half of its existence, the PfP Consortium embodied a bottom-up model of international cooperation based on the notion that dedicated people will do what needs to be done, within the limits of their capacity to help. Through the efforts of these dedicated individuals, the Consortium provided a family of publi- 
cations that covers the full range of security studies, to an international standard of excellence, serving the military, civilian, and academic needs of the Consortium membership. The Partnership for Peace Information Management System (PIMS) established the PfP Consortium website to facilitate the PfP Consortium's ability to function as a virtual organization, which was ultimately the primary means by which the community it engendered has sustained itself as the effort matured in support of more project-oriented goals. As the Consortium began to focus on project-oriented tasks, it revealed that any vision of how knowledge is created and disseminated must remain firmly connected to the strategy of intellectual capacity building. In the case of the Consortium's mission, this has meant promoting a competent security sector within civil society, emphasizing civilian participation as a measure of success, and preserving inviolate the concept of intellectual freedom.

\section{Conclusion: The "Community of Experts" Approach and Social Networks of Security Cooperation as a Model for the Future}

The history and development of the Partnership for Peace Consortium show that the Consortium successfully met the challenges it was created to address, greatly aiding in the development of a civilian community of practice in defense and security affairs throughout the Euro-Atlantic community. It successfully gathered together a wide array of institutions and activists engaged in a constructivist quest to co-develop a previously non-existent community of experts composed of both Allies and Partners. Binding them together was a shared commitment to transform the Partnership for Peace into a cooperative security network for the new millennium. While acknowledging the principle that education and training are ultimately national responsibilities, participants determined nevertheless to build upon these efforts by working to make multinational education and training a multinational responsibility. In so doing, they made great strides in building a cooperative network where participants could concentrate energy and resources by collecting and sharing educational materials and approaches.

The Consortium helped to align individual and organizational interests at a time of changing values and national interests among both Allies and Partners. Both the military and the civilian defense intellectual community need to confront the fact that insecurity in the postmodern world order arises from the disintegration and fragmentation of older forms of order and control. In response, there is a rising need to invest the informal authority for promoting change within civil society to a self-identifying "community of experts" who can engage in the mobilization of new forms of relevant knowledge.

As NATO prepares to celebrate its sixtieth anniversary in 2009, it is apparent that the entire Partnership concept, including the PfP Consortium, is ready for re-examination and refurbishment to support an agenda of expanding NATO's outreach to other regions of the world. Secretary-General Jaap de Hoop Scheffer's encouraged the attendees of the Consortium's tenth anniversary conference to press ahead, arguing that "the PfP Consortium deserves every possible support, because education is the best investment in our security.” He further reminded us that: 
Partnership was a creation of the second phase of NATO. It was a means to consolidate Europe- to turn it into an undivided security space geared towards cooperative security. Today, we are in the third phase of NATO-in the era of global challenges. And Partnership has come along with us into this new era. This is true for its military-operational dimension, but certainly also for its educational dimension. ${ }^{16}$

Established as part of the NATO-PfP Education and Training Enhancement Program (TEEP) at NATO's fiftieth anniversary at the Washington Summit in 1999, the PfP Consortium is ready-along with all of the other elements of TEEP, including the PfP Simulation Network and the PfP Training Centers - to be reinvented to commence its journey for the next ten years. The Consortium's first decade was marked by great achievements, and also by a process of maturity reaching toward becoming an artifact of community memory, as the original concept both fulfilled its primary mission and became refocused on smaller and more discrete tasks. The process of reinvention should concentrate on preparing all of the elements of TEEP, but particularly the Consortium, for new missions, mandates, and strategic purposes in support of NATO's engagement with regions of the world that lie beyond the scope of the original geographic scope of the Partnership for Peace, which has progressively diminished with each round of NATO enlargement.

On a global basis, one finds that, wherever the development of civilian expertise in military affairs is either neglected or actively thwarted - especially in civil society, the media, and academia - the democratic experiment is in jeopardy. The trend line in the evolution of civil society also influences military organizations, and helps determine how military leaders react to that evolution. The modern military officer has to be adaptive with civilians in support of new socio-political circumstances. Throughout its history, NATO reports repeatedly endorsed the work of the PfP Consortium as being central to the Euro-Atlantic community's transformation agenda. ${ }^{17}$ At the same time, the concept of the PfP Consortium of Defense Academies and Security Studies Institutes appears to have a timeless relevance, and is a worthy model for adaptation and replication in the context of global partnerships. Its enduring relevance was reflected in its very first artifact: its logo. ${ }^{18}$ The image of Athena-the goddess of warriors and heroes, but also the goddess of civilization and wisdom—viewed through a mesh net, her with spear in hand, while contemplating what might be imagined as the helmet of a fallen soldier, fittingly evokes the themes of the Consortium. While the boundaries of the Consortium are obscure, the enduring purpose of the "community of experts" model is clear: a deep contemplation of humanity's ultimate state of affairs and the sacrifices that accompany them.

16 Jaap de Hoop Scheffer, Opening Speech, 18 June 2008.

17 This was accomplished in Annual Reports on the Training and Education Enhancement program by the International Staff, and in Military Committee Memorandum MCM 064-03. 
THE QUARTERLY JOURNAL

\section{Bibliography}

Donnelly, Christopher. "Reform Realities." In Post-Cold War Defense Reform. Washington, D.C.: Brassey, 2002.

Joo, Rudolf. Democratic Control of Armed Forces. Paris: Institute for Security Studies of WEU, February, 1996 